\title{
Cerebrospinal Fluid and Blood Thiamine Concentrations in Phenytoin-Treated Epileptics
}

\author{
M.I. BOTEZ, CLAUDE JOYAL, URS MAAG and JOCELYNE BACHEVALIER
}

SUMMARY: Thiamine and folate levels in blood and cerebrospinal fluid (CSF) were determined by microbiological assays in 23 control subjects and 11 phenytoin-treated epileptics. There was no significant difference between the two groups for serum and CSF folate levels. There was, however, a statistically significant difference between the groups for both whole blood thiamine and CSF thiamine levels. Epileptic patients being treated with phenytoin had lower values than control subjects $(p<0.001)$

RESUMÉ: Nous avons déterminé les taux de la thiamine et des folates dans le sang et dans le liquide céphalorachidien chez 23 patients témoins et chez 11 malades épileptiques traités à la phénytoine. Les déterminations ont été faites par des méthodes microbiologiques. En ce qui concerne les taux des folates il n'y avait pas de différence significative entre les deux groupes. Il $y$ avait cependant une différence statistiquement significative entre les deux groupes autant pour les taux de la thiamine sanguine que pour ceux de la thiamine dans le liquide céphalo-rachidien: les malades épileptiques traités à la phénytoine ont présenté des taux inférieurs de la thiamine par rapport au groupe-témoin ( $p$ $<0.001$ ).

From the Service of Neurology, Hôtel-Dieu Hospital and Clinical Research Institute of Montreal and Department of Computer Sciences and Operation Research, University of Montreal.

Reprints Requests to: Dr. M.I. Botez, Clinical Research Institute of Montreal, 110 Pine Avenue West, Montreal, Quebec, H2W IR7, Canada.

Presented at the 16th Canadian Congress of Neurological Sciences, Calgary, Alberta, June 1981.

\section{INTRODUCTION}

The etiology of the chronic neuropsychiatric side-effects of phenytoin (PHT) is still unknown (Laxer et al., 1980).

There is evidence that PHT-induced polyneuropathy may be of two basic types. One is a reversible pharmacologic phenomenon associated with acute toxicity in man (Hopf, 1968; Birket-Smith and Krogh, 1971) and animals (Marcus et al., 1981), without morphological counterpart. The other type of peripheral nerve dysfunction is a mild non-reversible axonal neuropathy in epileptics who have received large amounts of PHT over many years - usually greater than 10 (Eisen et al., 1974; Chokroverty and Sayeed, 1975). In this form of chronic polyneuropathy, a deficiency of folate (Shorvon, 1979; Figueroa et al., 1980) or of vitamin $B_{12}$ (Frenckel et al., 1973) has been incriminated.

The role of folate as causal factor of PHT-induced polyneuropathy is controversial because (i) some authors did not find any improvement of the polyneuropathy after folate replacement therapy (Horwitz et al., 1968) while others did (Figueroa et al., 1980) and, (ii) several authors (Lovelace and Horwitz, 1968; Chokroverty and Sayeed, 1975) did not find any correlation between the presence and severity of polyneuropathy and folate levels.

The PHT-induced polyneuropathy is of axonal type (Shorvon, 1979) in contrast to folate deficiency polyneuropathy which seems to be demyelinating in nature (Botez et al., 1978).

To our knowledge, there is no data in the literature concerning cerebrospinal fluid (CSF) and blood thiamine levels in relation to PHT treatment.

PATIENTS AND METHODS

The 23 control subjects fulfilled the following conditions: a) they did not display any gastrointestinal or metabolic disease; b) they were not taking any kind of vitamin or any kind of drug interfering with absorption or metabolism of B group vitamins; c) they did not exhibit neurologic or psychiatric manifestations which could have resulted from a nutritional or metabolic disease. Bedridden patients as well as alcoholic patients were excluded from this study. There were 4 patients with transient ischemic attacks, 6 with lumbar disc herniation and 5 with normal pressure hydrocephalus. The remaining 8 control subjects were spouses of the epileptic patients and had a diet similar to that of the patients. The control group represented a group of general population in whom about fifteen percent had low serum folate values, a fact which is in agreement with previous Canadian epidemiological survey (Nutrition Canada, 1975).

All epileptic patients who were also alcoholics were excluded from this study. The PHT-treated epileptic group (11 Ss) included only patients who had been taking $300 \mathrm{mg}$ PHT daily for more than ten years and had not received any other anticonvulsant drugs during the last three years. The PHT-plasma levels on the day of vitamin determinations were within the normal therapeutic range. Three patients from this group had clinical and electrophysiological evidence of PHT-induced polyneuropathy.

The serum and CSF folate levels were determined using Lactobacillus casei ATCC 7649 (Wells and Casey, 1967). The whole blood and CSF thiamine levels were assayed in duplicate, using Lactobacillus fermenti ATCC (Baker and Frank, 1968). An internal control procedure was added, especially in those cases in whom a low blood thiamine value was found. Since 
TABLE 1

Folate and thiamine values in controls and PHT-treated epileptics

\begin{tabular}{llccccc}
\hline & & Age & Serum folate* & CSF folate* & Blood thiamine* & CSF thiamine \\
\hline $\begin{array}{l}\text { Control } \\
\text { group }\end{array}$ & Mean \pm S.D. & $53.6 \pm 15.5$ & $6.22 \pm 5.24$ & $18.01 \pm 6.02$ & $68.62 \pm 14.04$ & $44.04 \pm 6.90$ \\
$\begin{array}{l}\text { (14M, } 23 \\
\text { MF) }\end{array}$ & Median & 56 & 4.6 & 16.8 & 68.33 & 43.5 \\
& Range (min-max) & $18-76$ & $2.0-26.0$ & $9.5-28.0$ & $43.3-88.3$ & $32.4-57.4$ \\
\hline $\begin{array}{l}\text { PHT-treated } \\
\text { epileptic }\end{array}$ & Mean \pm S.D. & $46.5 \pm 15.4$ & $7.42 \pm 5.61$ & $18.63 \pm 6.65$ & $44.27 \pm 16.76$ & $21.27 \pm 11.12$ \\
$\begin{array}{l}\text { group } \\
\text { N=11 }\end{array}$ & Median & 50 & 6.6 & 21.0 & 38.3 & 19.6 \\
\hline Wilcoxon, Mann-Whitney & Range (min-max) & $23-69$ & $1.4-18.0$ & $5.4-29.0$ & $25.0-83.3$ & $1.7-40.0$ \\
\hline
\end{tabular}

- Values expressed in $\mathrm{ng} / \mathrm{ml}$

the data showed heterogeneity of variance and lack of normality, we chose the Wilcoxon rank sum test (Bradley, 1968) to compare the two groups.

\section{RESULTS}

The results are summarized in Table 1. There was no significant age difference between the controls and the epileptic patients. Serum and CSF folate levels did not differ significantly for the two groups ( $p>0.2$ ). It can therefore be concluded that, despite the fact that some PHT-treated epileptics develop a folate deficient megaloblastic anemia, overall there is no significant difference in folate values between controls and PHT-treated epileptics. However, blood thiamine and CSF thiamine levels were significantly ( $p<$ 0.001 ) lower in the PHT group compared with the controls.

\section{DISCUSSION}

It is known that PHT impairs folate absorption and folate synthesis (Kutt and Solomon, 1980). A similar mechanism could be responsible for the low thiamine values found in the present study of PHT-treated epileptics.

Our data for serum folate values are in agreement with those of Reynolds et al. (1971) who did not find any significant difference in serum folate levels between a control group and an outpatient epileptic group. Our PHTtreated epileptics were also outpatients and did not display any evident psy- chiatric illness. Reynolds et al (1971) did document significant lowering of serum and red blood cell folate only in institutionalized psychiatric epileptic patients.

The abnormally low thiamine values in both whole blood and CSF in PHTepileptics raise some important questions for future research in this field. What is the possible role of thiamine in the pathogenesis of PHT-induced polyneuropathy? To what extent is the PHT induced chronic cerebellar ataxia (Ghatak et al., 1976) correlated with a lowering of thiamine levels? What is the mechanism by which PHT lowers the levels of CSF 5-hydroxyindoleacetic acid (Young et al., 1980)? Both folate (Botez et al., 1979; Singer et al., 1980) and thiamine (Plaitakis et al., 1978) deficiencies are accompanied by disorders of serotonin metabolism. Further studies are needed in both humans and animals to verify to what extent the disturbed serotonin metabolism is correlated not only with folate values as has been already emphasized (Young et al., 1980) but also with thiamine metabolism. These preliminary findings require verification in a larger number of patients, using not only the microbiological assay but also the transketolase activity assay (Brin, 1962). Careful dietary assessments will also be needed to differentiate thiamine deficiencies due to dietary factors from those related to drug administration.

\section{ACKNOWLEDGEMENTS}

Supported by grants from the C.O. Monat and Hôtel-Dieu Foundations and Dow Pharmaceuticals of Canada. Thanks are due to Miss Claire Vézina for technical assistance.

\section{REFERENCES}

BAKER, H. and FRANK, O. (1968). In: Clinical Vitaminology, Inter-science Publishers, J. Wiley and Sons, New York, pp. 721.

BIRKET-SMITH, E. and KROGH, E. (1971). Motor nerve conduction velocity during diphenylhydantoin intoxication. Acta Neurol. Scand., 47, 265-271.

BOTEZ, M.I., YOUNG, S.N., BACHEVALIER, J. and GAUTHIER, S. (1979). Folate deficiency and decreased brain 5 hydroxytryptamine synthesis in man and rat. Nature, 278, 182-183.

BOTEZ, M.I., PEYRONNARD, J.M., BACHEVALIER, J. and CHARRON, L. (1978). Polyneuropathy and folate deficiency. Arch. Neurol., 35, 581-584.

BRADLEY, I.V. (1968). In: Distribution-Free Statistical Tests Prentice-Hall, Englewood Cliffs, Section 5.8 .

BRIN, M. (1962). Erythrocyte transketolase in early thiamine deficiency. Ann. N.Y. Acad. Sci., 98, 528-531.

CHOKROVERTY, S. and SAYEED, Z.A. (1975). Motor nerve conduction study in patients on diphenylhydantoin therapy. $\mathbf{J}$. Neurol. Neurosurg. Psychiat. 38, 1235. 1239.

EISEN, A.A., WOODS, J.F. and SHERWIN, A.L. (1974). Peripheral nerve-function in long-term therapy with diphenylhydantoin. Neurology 24, 411-417. 
FIGUEROA, M.A., JOHNSON, R.H., LAMBIE, D.G. and SHAKIR, R.A. (1980). The role of folate deficiency in the development of peripheral neuropathy caused by anticonvulsants. J. Neurol. Sci., 48, 315-323.

FRENKEL, E.P., MCCALL, M.S. and SHEEHAN, R.G. (1973). Cerebrospinal fluid folate and vitamine $B_{12}$ in anticonvulsant induced megaloblastosis. J. Lab. Clin. Med., 81, 105-115.

GHATAK, N.R., SANTOSO, R.A. and McKINNEY, W.M. (1976). Cerebellar degeneration following long-term phenytoin therapy. Neurology, 27, 818-820.

HOPF, H.C. (1968). Effect of diphenylhydantoin on peripheral nerves in man. Electroencephalography and Clinical Neurophysiology, 25, 411.

HORWITZ, S., KLIPSTEIN, F. and LOVELACE, R. (1968). Relation of abnormal folate metabolism to neuropathy developing during anticonvulsant drug therapy. Lancet, i, 563-565.

KUTT, H. and SOLOMON, G.E. (1980). Phenytoin: relevant side-effects. In: Antiepileptic Drugs: Mechanisms of Action, eds
G.H. Glaser, J.K. Penry and D.M. Woodbury. Raven Press, New York, pp. 435-445.

LAXER, K.D., ROBERTSON, L.T., JULIEN, R.M. and DOW, R.S. (1980). Phenytoin: relationship between cerebellar function and epileptic discharges. In: Antiepileptic Drugs: Mechanisms of Action, eds. G.H. Glaser, J.K. Penry and D.M. Woodbury. Raven Press, New York, pp. 415-426.

LOVELACE, R.E. and HORWITZ, S.J. (1968). Peripheral neuropathy in long-term dyphenylhydantoin therapy. Arch. Neurol. (Chic.), 18, 69-77.

MARCUS, D.J., SWIFT, T.R. and McDONALD, T.F. (1981). Acute effects of phenytoin on peripheral nerve function in the rat. Muscle and Nerve, 4:48-50.

NUTRITION CANADA (1975). The Quebec Survey Report. A report from the Nutrition Canada by the Bureau of Nutritional Sciences. Ottawa, Department of National Health and Welfare, pp. 119-120.

PLAITAKIS, A., NICKLAS, WJ., BERL, S. (1978). Thiamine deficiency: selective impairment of the cerebellar serotonergic system. Neurology, 28, 691-698.
REYNOLDS, E.H., PREECE, J. and JOHNSON, A.L. (1971). Folate metabolism in epileptic and psychiatric patients. J. Neurol. Neurosurg. Psychiatry, 34, 726-732.

SHORVON, S.D. (1979). Anticonvulsant therapy and peripheral neuropathy. In: Folic Acid in Neurology, Psychiatry and Internal Medicine, eds. M.I. Botez and E.H. Reynolds. Raven Press, New York, pp. 335348.

SINGER, H.S., BUTLER, I., ROTHENBERG, S., VALLE, D. and FREEMAN, J. (1980). Interrelationships among serum folate, CSF folate, neurotransmitters and neuropsychiatric symptoms. Neurology, 30 , 419.

YOUNG, S.N., GAUTHIER, S., ANDERSON, G.M. and PURDY, W.C. (1980). Tryptophan, 5-hydroxyindoleacetic acid and indoleacetic acid in human cerebrospinal fluid: interrelationships and the influence of age, sex, epilepsy and anticonvulsant drugs. J. Neurol. Neurosurg. Psychiatry, 143, 438 445.

WELLS, D.G. and CASEY, H.J. (1967). Lactobacillus casei CSF folate activity. $\mathrm{Br}$. Med. J., 3, 834-835. 